\title{
Investigation of Bipolar Plate Materials for Proton Exchange Membrane Fuel Cells
}

\author{
S. Shimpalee ${ }^{\mathrm{a}, \mathrm{d}, 1}$, V. Lilavivat ${ }^{\mathrm{b}}$, H. McCrabb ${ }^{\mathrm{c}}$, Y. Khunatorn ${ }^{\mathrm{d}}$, H-K Lee Ke W-K Lee $^{\mathrm{e}}$, \\ and $J$. W. Weidner ${ }^{\mathrm{a}}$
}

\author{
a Department of Chemical Engineering, \\ University of South Carolina, Columbia, SC 29208 \\ ${ }^{\mathrm{b}}$ National Metal and Materials Technology Center \\ NSTDA, Thailand \\ ${ }^{\mathrm{C}}$ Faraday Technology, Inc. \\ 315 Huls Drive, Clayton, OH. 45315 \\ ${ }^{\mathrm{d}}$ Department of Mechanical Engineering \\ Faculty of Engineering \\ Chiang Mai University \\ Chiang Mai, 50200, Thailand \\ ${ }^{\mathrm{e}}$ Hydrogen Fuel Cell Regional Innovation Center \\ Woosuk University \\ Jeonju, Korea
}

Submitted to

International Journal of Hydrogen Energy

Submitted to as Technical Paper

Revised Version: 05/09/2016

1- Corresponding author: Phone: (803) 576-6140; FAX: (803) 777-8142, e-mail: shimpale@cec.sc.edu 


\begin{abstract}
Low-cost parts, materials, and production methods are important for effective establishment of polymer electrolyte membrane fuel cells (PEMFCs) into the commercial marketplace. The bipolar plate is one part that substantially impacts the PEMFC manufacturing cost. Metallic bipolar plates are an attractive alternative to graphite because they provide the necessary electrical and thermal conductivity and they offer good mechanical strength which supports the forces within the stack. Stainless steel, which is reasonably cheap, a good conductor, and corrosion resistant with high strength, has exhibited acceptable performance as a bipolar plate for several thousand hours of experiments. In this work, a through-mask electro-etching process was selected for fabrication of 304L and 430 stainless steel alloy bipolar plates for 25$\mathrm{cm}^{2}$ PEMFC and they were compared against the graphite material. The key results revealed that stainless steel bipolar plates give comparable performance to graphite plates especially under well humidified conditions. At drier conditions, the resistance is the largest factor on the overall performance for all bipolar plate materials. Toray paper and Carbel CL GDLs give different performances under various bipolar plate materials and operating conditions. It is also shown that significant differences in channel depth profiles affect the overall performance.
\end{abstract}

Keywords: PEM; Fuel cells; Bipolar plate manufacturing; Stainless Steel Grades; Gas Diffusion Layer; Channel Depth Profile. 


\section{Introduction}

With the demand of energy consumption continuously increasing every year along with the depletion of resources, the development and research on alternative energy is necessary to mitigate this energy issue. Polymer Electrolyte Membrane Fuel Cells (PEMFCs) are that alternative energy technology, producing electricity from electrochemical reactions without combustion. Moreover, PEMFCs operate at low temperature and pressure while having fast startup and shutdown times with low noise and high efficiency. PEMFCs can meet high power demands for residences and electrical vehicles while also being applicable for low power devices such as electronics.

Low-cost materials and production methods are necessary for fruitful incorporation of PEM fuel cells into the commercial energy sector. The bipolar plate is one part that impacts the manufacturing cost of the PEMFC substantially [1]. Graphite has been broadly used for bipolar plates in laboratory scale research due to its sufficient electrical conductivity, good corrosion resistance, and light weight, but manufacturing precise flow-field channels in the graphite is hard and costly. Moreover, there are mechanical concerns, such as the fragility of thin graphite plates within the stack that have led to the exploration of different bipolar plate materials. Metallic bipolar plates are strong candidates for replacing graphite, offering great electrical and thermal conductivity while offering effective mechanical strength to support the forces within the stack even at a thinner plate thickness [2-7]. Stainless steel (SS) has shown satisfactory performance as a bipolar plate for thousands of hours of testing [8,9]. Moreover, in the development of manufacturing for metal bipolar plates, the variations in channel depth and undercut for any mask or pattern might be expected [10-18]. Further, machining tolerances and tool deterioration could cause a variance in laboratory plates obtained from various vendors. So that modeling 
work performed looked at effects of the typical variation in channel undercut, bending angle, and channel depth. The predictions suggested that the small tolerances should not impact the overall performance and durability of fuel cells [19]. Nevertheless, the effect of austenitic and ferritic grades in stainless steel was missing in that study and it was furthermore complicated to evaluate its impact on the fuel cell performance using a numerical technique.

For this work, two different types of SS bipolar plates were selected together with standard graphite material for evaluation and justification. The effect on the performance from the carbon paper, gas diffusion layer (GDL), and carbon clothe GDL combined with SS bipolar plates were accounted for. Finally, the different channel depth profiles for the flow-fields in the bipolar plates were considered so as to take into account the malfunctions in the manufacturing process. The outcomes of this study will provide insight into understanding how different materials used for bipolar plates impact the fuel cell performance with various GDLs, operating conditions, and manufacturing errors.

\section{Experimental Procedure:}

\section{Fuel Cell Setup and Polarization Measurements}

Two types of Stainless Steel (SS) fuel cell flow-field plates from Faraday Technology, Inc. (Clayton, OH, USA.) with an active area of $25 \mathrm{~cm}^{2}$ were employed in the tests along with a standard $25 \mathrm{~cm}^{2}$ graphite fuel cell. Through-mask electro-etching was used for constructing the flow-field plates $[10,11]$. This specific technique uses standard photolithography to pattern the surface of the bare, flat metallic substrate to protect specific areas during the etching process. An electric field is applied between the patterned bipolar plate substrate and a counter electrode submerged in an electrolyte solution to electrochemically remove the exposed metal not 
protected by the photoresist mask. Once the etching process is complete, the photoresist is removed from the substrate to reveal the surface features, e.g. gas flow field channels. The cell consisted of triple serpentine flow-field plates with anode and cathode co-current flows and in the experiments, PRIMEA ${ }^{\circledR}$ Series 57 MEAs from W. L. Gore \& Associates, Inc. (Elkton, MD, USA.) were used. The MEAs contained $0.1 \mathrm{mg} \mathrm{Pt} / \mathrm{cm}^{2}$ in the anode, $0.4 \mathrm{mg} \mathrm{Pt} / \mathrm{cm}^{2}$ in the cathode, and a membrane with a $35 \mu \mathrm{m}$ nominal thickness. Toray ${ }^{\mathrm{TM}}$, TGP-H-060, was employed as gas diffusion layer (GDL) as described above. Silicone coated glass fiber with a thickness of $178 \mu \mathrm{m}$ (7 mil) from Saint-Gobain (Hoosick Falls, NY, USA) was used as a gasket during the assembly of the cell.

The experiments were conducted using a fuel cell test station model 890B from Scribner and Associates Inc. (Southern Pines, NC, USA). High purity hydrogen (99.997\%) and compressed air were supplied to the anode and cathode, respectively. Three operating conditions were performed as shown in Table 2. Each test cell was broken-in by repeatedly running this procedure, OCV-0.6V-OCV-0.4V-OCV, and each potential was held for 30 sec. A total of 2x40 cycles of this procedure was applied for conditioning procedure of PRIMEA ${ }^{\circledR} 57$ series. The polarization curve was obtained by varying the cell voltage from open circuit potential to $0.2 \mathrm{~V}$. At each point, the voltage was maintained for 15 min then the average current was recorded. Tables 1 and 2 present the detail flow-field geometry and the experimental conditions.

\section{Results and Discussion}

The effect of bipolar plate materials on PEMFC performance

Figure 1 shows the channel depth profiles of the flow-field plates from the electroetching process on the stainless steel (SS) 430 and the SS304L that gave an average channel 
depth of $0.4 \mathrm{~mm}$. The flow-field pattern was triple serpentine on a $25-\mathrm{cm}^{2}$ reaction area fuel cell. The results from this study were compared to a baseline graphite plate on a $25-\mathrm{cm}^{2}$ reaction area fuel cell. All fuel cell's flow-field plates were assembled in the co-current flow direction.

Before performing performance tests or polarization, it is important to know the resistance of the materials (e.g., SS430, SS304L, and graphite). Therefore, the resistance measurements were collected before the performance test and also after the final eighth test of the experiment under the contact compression torque of $4.52 \mathrm{~N}-\mathrm{m}$ (40 in- $\mathrm{lb}_{\mathrm{f}}$ ) per bolt. Experiments were performed continuously for approximately 100 hours, and all bipolar plates were subjected to the same procedure. It is also noted that the resistance was measured only for the bipolar plate. For the SS304L, the resistance was measured as $0.54 \mathrm{~m} \Omega$ before and $1.68 \mathrm{~m} \Omega$ after the experiment. The resistance of the SS430 is $0.88 \mathrm{~m} \Omega$ before and $1.59 \mathrm{~m} \Omega$ after the experiment. The resistance of the graphite plate was measured before and after experiments as $0.20 \mathrm{~m} \Omega$ and $0.19 \mathrm{~m} \Omega$, respectively. The resistance measurement of the SS430 was slightly less than the SS304L only after the experiment. For stainless steel, the resistance slightly increases after eight cycles of polarization measurements. This could be due to the growth of the metal oxide film on the SS surface during the electrochemical reaction inside the fuel cell [20]. The graphite plate shows the lowest resistance when compared with the SS plates. Note that the intent of this study was to establish and report the standard baseline for cell performance using SS and graphite bipolar plates without any surface treatment or modification to enhance the bipolar plate corrosion resistance.

Figures 2 to 4 show polarization curves for the three operating conditions provided in Table 2 for three bipolar plate materials. Again, the Toray ${ }^{\mathrm{TM}}$ TGP-H-060 GDL was used for all cases. In each figure, there are two sets of polarization curves. The first set is the original data 
and the second set is the data after correcting for resistance of materials. It is noted that the overall cell resistance used for the correction was measured during the experiment by performing high frequency resistance (HFR) from the fuel cell test station. By correcting for all the resistance from the original experimental data, the results should only represent the effect of surface structure once other components (i.e., MEA, GDLs, gaskets) are the same. Figure 2 presents polarization curves when stationary operating condition was set. The results show that all flow-field plates give similar performance from open circuit potential until $\sim 0.7 \mathrm{~V}$ then the performance of the fuel cell using the graphite plate starts to drop, followed by the SS430 and finally the SS304L. These results also agree with the iR corrected polarization curves but their performance is much higher than the original data as expected. From this result, it appears that the material resistance has minimal effect on the cell performance when the humidity condition of the cell is high. The change in performance could be due to other effects such as water flooding.

When the inlet humidity condition is set to a dryer condition as shown in Figure 3, the original performance curve of the SS304L shows the lowest performance and the graphite flowfield plate gives the highest performance. After removing the effect of ohmic resistance as shown in the iR corrected data, both SS430 and SS304L give the highest performance and the graphite plate shows similar performance as SS plates until the current density reaches $1000 \mathrm{~mA} / \mathrm{cm}^{2}$. Then the performance of the fuel cell using graphite flow-field plate drops. This could be due to accumulation of liquid water starting to block the flow-field channel, which is more difficult to remove from the graphite plate when compared with the SS plates [22].

Figure 4 presents the performance curves under automotive condition where the cathode humidity is completely dry and the system pressure of the fuel cell was more than twice that of 
the atmospheric pressure. The results for the stainless steel plates show much higher performance than the cases for both stationary and dryer conditions. Alternatively, the graphite plate presents worse performance than the one shown in the dryer condition (Figure 3) especially when the current density is higher. After iR correction, the results clearly reveal that the performance of fuel cell using graphite plate gives the lowest performance when current density is above 1000 $\mathrm{mA} / \mathrm{cm}^{2}$. Again, the significant drop in performance could be due to the blockage of liquid water in the graphite flow-field channel caused by water condensation inside the fuel and its removal is harder when compared with the SS plates.

Summarizing the results from Figures 2 to 4, the fuel cell using either SS304L or SS430 as the flow-field plates gives similar results under the dryer humidity conditions after correcting for iR (e.g., Figures 3 and 4). Nevertheless, in the original data, the SS304L gives higher performance than the SS430 only at the stationary condition when all inlet gases are fully humidified. For the graphite plate, the original data shows that it gives higher performance over both SS304L and SS430 when the current density is below $1000 \mathrm{~mA} / \mathrm{cm}^{2}$ for dry conditions and when it is below $400 \mathrm{~mA} / \mathrm{cm}^{2}$ for stationary condition. This is because the graphite plate has lower resistance compared to the SS plates. If not for high possibility of the water blockage at higher current densities the graphite could perform much better. The water droplets from condensation can occur inside the channel and the capability to remove liquid water from the channel is inadequate for the graphite plate compared to the SS plates. Figure 5 shows the experimental evidence of liquid water droplet motion on the SS304L, the SS430, and the graphite plates at different Reynolds' number [21, 22]. The experimental results show that it requires the flow rate of $\mathrm{Re}>555$ to remove $10 \mu \mathrm{L}$ droplet on the SS304L surface and $\mathrm{Re}>740$ to remove the droplet on the SS430 surface, when both surfaces are relatively smooth with an 
average surface roughness ( $\mathrm{Ra}$ ) of $0.3 \mu \mathrm{m}$. It is noted that for the surface roughness measurement of each SS material, the electrochemical manufacturing process enables one to tailor the surface finish of the channels to minimize its impact on water management during fuel cell operation. During or immediately after channel formation, the electric field parameters may be selected to achieve the desired surface roughness through electropolishing of the surface. The surface finishes investigated during analyses, observations, and predictions of liquid droplet movement were typical of what one might expect during electrochemical etching for channel formation with these widths and depths on metallic bipolar plates. For the graphite plate with an average surface roughness ( $\mathrm{Ra}$ ) of $1.0 \mu \mathrm{m}$ [23], it requires the flow rate of $\mathrm{Re}>1295$ to remove $10 \mu \mathrm{L}$ droplet from its surface. In Figure 5, the iR corrected polarization curves can be compared with the droplet motion study from the previous work [22]. It shows that the graphite plate gives the worst performance at the operating condition that may promote flooding (i.e., stationary condition, dryer condition). When there is liquid water inside the PEMFC, the liquid water needs to quickly leave the cell through the flow-field channel. Therefore, a material with higher surface roughness (i.e., graphite) can cause water blockage inside the channel thus, reducing the PEMFC performance.

\section{The effect of GDL material on PEMFC performance}

In this study, two different gas diffusion layers (GDLs) were selected for performance tests on both SS304L and SS430. The first GDL is carbon paper material called Toray ${ }^{\mathrm{TM}}$ TGP-H060 and the second GDL is carbon cloth material called Carbel CL ${ }^{\mathrm{TM}}$. The properties of both GDLs are also shown in Table 1. Three operating conditions were chosen same as the earlier experiments (Table 2). Figure 6 shows iR corrected polarization curves of those three operating 
conditions. For the conditions of drier inlet humidity and automotive operation, the effect of GDL material on both SS plates is insignificant. However, the SS430 with Cabel CL $^{\mathrm{TM}}$ GDL shows slightly higher performance over others. This could be due to the surface structure of SS 430 that works well with the Cabel CL GDL and when the operating conditions minimize the possibility for water condensation. For Stationary conditions where all gases are well humidified and there exists the possibility of liquid water flooding in the fuel cell, the carbon cloth GDL gives higher performance than carbon paper GDL for both SS304L and SS430 flow-field plates. Both SS plates give similar performance under carbon cloth GDL although the SS430 shows slightly higher performance than the SS304L. For the carbon paper, the SS304L devotes higher limiting current density than the SS430. This agrees well with the analysis shown in Figure 5 where the SS430 shows lower ability to remove the liquid water from its surface than the SS304L.

The effect of channel depth uniformity on PEMFC performance

The effect of channel depth uniformity on the SS plates on PEMFC performance is analyzed in this section. Faraday Through-mask Electro-etching process can be used to create flow-field channels in a typical fashion and design character. During the manufacturing process, the channel dimensions, such as the uniformity of channel depth and/or cross could be offset from the design. This offset in channel dimension could impact the performance and durability of PEMFC [9]. In this work, the linear profiles of the channel depths from inlet to outlet and from outlet to inlet were set to be performed and compared with the baseline uniform channel depth as shown in Figure 7. The channel depth profiles were obtained with a Mitutoyo Surftest SJ-401 contact surface roughness tester at a traverse rate of $0.5 \mathrm{~mm} \mathrm{sec}{ }^{-1}$ utilizing a standard 
diamond stylus with a tip angle and radius of $90^{\circ}$ and $5 \mu \mathrm{m}$ respectively. Note that all linear channel depth profiles for the PEMFC flow-field have an averaged channel depth of $0.4 \mathrm{~mm}$ similar to the channel depth of the baseline flow-filed.

Figure 8 shows performance curves of three different channel depth profiles given in Figure 7 on SS304L and SS430 under dryer operating condition. Both original data and iR corrected data are presented. From this figure, both SS304L and SS430 give similar performance for each channel depth profile. The channel depth profile where the inlet has the deepest channel gives the highest performance and the plate with the deepest channel at the outlet gives the lowest performance. These results are consistent with both original data and iR corrected data. However, when the operating condition was changed to automotive condition where the back pressure is increased to $274 \mathrm{kPa}$ as shown in Figure 9, the effect of stainless steel's depth profile on the PEMFC is not significant under iR corrected data. Both SS materials give similar performance and the effect of channel depth profile is also minimal. Nonetheless, the fuel cell's flow-field channel with uniform and deep-outlet profiles show slightly higher performance than the fuel cell with the deep-inlet profile. Furthermore on the uniform plate, the SS430 shows higher performance than the SS304L.

Figure 10 presents the polarization curves of fuel cell with different channel depth profiles of SS plate under stationary operating condition. The performance of the fuel cell with deep-outlet channel depth flow-field plate shows the highest performance and the uniform channel depth flow-field plate fuel cell gives the lowest performance for both SS304L and SS430 materials. The significant drop in the fuel cell performance of both deep-inlet channel and uniform channel flow-fields could be due to water flooding inside the fuel cell, which is hard to remove when compared to the deep-outlet channel flow-field. As mentioned earlier, for the deep- 
outlet channel flow-field, the cross section area of flow-field channel is getting bigger from inlet toward the outlet, thus creating less opportunity of water blockage inside the channel.

\section{Conclusions:}

For PEM fuel cells to be successfully implemented into the commercial marketplace, an inexpensive, high volume bipolar plate manufacturing process will need to be developed. This work describes the impact of the selected stainless steel materials for bipolar plates on the change in performance. Furthermore, the tolerance of channel dimension from through-mask electro-etching process for fabrication of gas flow-field channels was also considered.

From this study it can be concluded that the resistance of the bipolar plate has less of an impact on the performance when the humidity condition is higher and the SS 304L gives the best performance. However when the humidity condition is lower, the resistance of bipolar plate material can be the key factor of affecting the change in performance and cell degradation. Therefore, the lower resistance material gives higher overall performance. Also, the surface roughness of material controls the water removal from the cell and will be key to controlling the PEMFC performance once the degree of flooding is high. The channel offset from manufacturing process causing non-uniform characteristic will impact the consistency in overall performance. The effect of surface treatment will be included for the future studies.

\section{Acknowledgement:}

This work was supported by the DOE under Grant No. DE-FG02-08ER85112 and the NSF-Industry/University Cooperative Research Center for Fuel Cells (Grant No. EEC-0324260). The authors would like to acknowledge the collaboration agreement between University of South 
Carolina, Woosuk University (Regional Innovation Center for Fuel Cell), and Chiang Mai University. Any opinions, findings, and conclusions or recommendations expressed in this material are those of the authors and do not necessarily reflect the views of the DOE or NSF. Finally, the authors greatly appreciated Mr. Cody Wilkins for his comments.

\section{References:}

1. B. Cunningham and D. Baird, "The development of economical bipolar plates for fuel cells," J. Mater. Chem., 16, 4385, 2006.

2. R. Taherian, “A review of composite and metallic bipolar plates in proton exchange membrane fuel cell: Materials, fabrication, and material selection,” J. of Power Sources, 265, 370-390, 2014.

3. S-P. Jung, C-I. Lee, C-C. Chen, W-S. Chang, C-C. Yang, "Development of novel proton exchange membrane fuel cells using stamped metallic bipolar plates,” J. of Power Sources, 283, 429-442, 2015.

4. H. Tawfik, Y. Hung, D. Mahajan, “Metal bipolar plates for PEM fuel cell-A review,” J. of Power Sources, 163, 755-767, 2007.

5. T-Y. Zhou, Y-S. Chen, "Effect of Channel Geometry on Formability of 304 Stainless Steel Bipolar Plates for Fuel Cells_-Simulation and Experiments,” J. Fuel Cell Sci., Technol., 12(5), 051001-051001-8, 2015.

6. S. Rajasekar, R. Chetty, L. Neelakantan, “Low-nickel austenitic stainless steel as an alternative to 316L bipolar plate for proton exchange membrane fuel cells,” Intl. J. of Hydrogen Energy, 40(36), 12413-12423, 2015.

7. J-C. Hung, D-H. Chang, Y. Chuang, “The fabrication of high-aspect-ratio micro-flow channels on metallic bipolar plates using die-sinking micro-electrical discharge machining," J. of Power Sources, 198, 158-163, 2012.

8. DP. Davis, PL. Adcock, M. Turpin and S.J. Rowen,” Stainless steel as a bipolar plate material for solid polymer fuel cells,” J. of Power Sources, 86, 237-242, 2000.

9. T.L. Smith, A.D. Santamaria, J.W. Park, K. Yamazaki,” Alloy selection and die design for stamped Proton Exchange Membrane Fuel Cell (PEMFC) bipolar plates,” Procedia CIRP, 14, $275-280,2014$.

10. H. McCrabb, A. Lozano-Morales, S. Snyder, L. Gebhart, EJ. Taylor, “Through mask electrochemical machining,” ECS Trans., 19 (26), 19, 2009. 
11. H. McCrabb, EJ. Taylor, A. Lozano-Morales, S. Shimpalee, M. Inman, JW. Van Zee, "Through-mask electro-etching for fabrication of metal bipolar plate gas flow field channels," ECS Trans., 33(1), 991, 2010.

12. M. Koc and S. Mahabunphachai, "Feasibility investigations on a novel micro-manufacturing process for fabrication of fuel cell bipolar plates: Internal pressure-assisted embossing of micro-channels with in-die mechanical bonding," J. of Power Sources, 172/2: 725-733, 2007.

13. S. Mahabunphachai and M. Koc, "Fabrication of micro-channel arrays on thin metallic sheet using internal fluid pressure: Investigations on size effects and development of design guidelines,” J. of Power Sources, 175/1: 363-371, 2009.

14. S. Mahabunphacha, ON. Cora, M. Koc, "Effect of manufacturing processes on formability and surface topography of proton exchange membrane fuel cell metallic bipolar plates," J. of Power Sources, 195/16, 5269-5277, 2010.

15. F. Dundar, E. Dur, S. Mahabunphachai, M. Koc, “Corrosion resistance characteristics of stamped and hydroformed proton exchange membrane fuel cell metallic bipolar plates,” J. of Power Sources, 195/1, 3546-3552, 2010.

16. C. Turan, ON. Cora, M. Koc, "Contact resistance characteristics of coated metallic bipolar plates for PEM fuel cells e investigations on the effect of manufacturing,” Intl. J. of Hydrogen Energy, 37, 18187-18204, 2012.

17. M.P. Brady, M. Abd Elhamid, G. Dadheech, J. Bradley, T.J. Toops, H.M. Meyer III, P.F. Tartorelli, "Manufacturing and performance assessment of stamped, laser welded, and nitrided FeCrV stainless steel bipolar plates for proton exchange membrane fuel cells,” Intl. J. of Hydrogen Energy, 38, 4734-4739, 2013.

18. Q. Hu, D. Zhang, H. Fu, K-K. Huang, "Investigation of stamping process of metallic bipolar plates in PEM fuel cell - Numerical simulation and experiments,” Intl. J. of Hydrogen Energy, 39, 13770-13776, 2014.

19. S. Shimpalee, V. Lilavivat, H. McCrabb, A. Lozano-Morales, J.W. Van Zee, "Understanding the effect of channel tolerances on performance of PEMFCs," Intl. J. of Hydrogen Energy, 36/19, 12512-12523, 2011.

20. M-S. Moon, K-D. Woo, S-J. Kang, J-H. Song, J-H. Oh, S-M. Yang, “A study of the corrosion behavior of STS304 and STS430, depending on surface pre-treatment conditions, in PEMFC while in operation,” Intl. J. of Precision Engineering and Manufacturing, 15, 6, 12011205, 2014.

21. V. Lilavivat, S. Shimpalee, J. W. Van Zee, H. McCrabb, and A. Lozano-Morales, "Fundamental Analyses, Observations, and Predictions of Liquid Droplet Movement on Etched-Metal Surfaces for PEMFC,” ECS Trans. 33 (1), 973, 2010. 
22. S. Shimpalee, V. Lilavivat, "Study of water droplet removal on etched-metal surfaces for proton exchange membrane fuel cell flow channel,” ASME J. Electrochem. En. Conv. Stor., 13(1), 011003-011003-7, 2016.

23. J. Doyle, G. Murray, "Surface roughness of moulded graphite composite bipolar plates," White Paper, Bac2 Conductive Composites Ltd., 2011. (www.bac2.co.uk)

\section{List of Tables:}

Table 1: Geometry details.

Table 2: Experimental condition. 


\section{List of Figures:}

Figure 1: Channel depth profiles from electro-etching process on SS430 and SS304L bipolar plates (Average depth $=0.4 \mathrm{~mm}$ ).

Figure 2: Polarization curves for serpentine flow-field plates under stationary condition. $\left(\mathrm{T}_{\text {cell }}=70^{\circ} \mathrm{C}\right.$, Anode/Cathode $\mathrm{RH}=100 / 100$, Anode/Cathode stoich $\left.=1.2 / 2.0, \mathrm{P}=101 \mathrm{kPa}\right)$ [GDL: Toray TGP-H-060, GORE ${ }^{\mathrm{TM}}$ PRIMEA $^{\circledR}$ SERIES 57 MEA (Pt: 0.1/0.4 mg/cm²)]

Figure 3: Polarization curves for serpentine flow-field plates under dryer condition. $\left(\mathrm{T}_{\text {cell }}=80^{\circ} \mathrm{C}\right.$, Anode $/$ Cathode $\mathrm{RH}=75 / 25$, Anode/Cathode stoich $\left.=1.3 / 2.0, \mathrm{P}=101 \mathrm{kPa}\right)$ [GDL: Toray TGP-H-060, GORE ${ }^{\mathrm{TM}}$ PRIMEA $^{\circledR}$ SERIES 57 MEA (Pt: 0.1/0.4 mg/cm²)]

Figure 4: Polarization curves for serpentine flow-field plates under automotive condition. $\left(\mathrm{T}_{\text {cell }}=80^{\circ} \mathrm{C}\right.$, Anode/Cathode $\mathrm{RH}=75 / 0$, Anode/Cathode stoich $\left.=1.3 / 2.0, \mathrm{P}=274 \mathrm{kPa}\right)$ [GDL: Toray TGP-H-060, GORE ${ }^{\mathrm{TM}}$ PRIMEA $^{\circledR}$ SERIES 57 MEA (Pt: 0.1/0.4 mg/ $\mathrm{cm}^{2}$ )]

Figure 5: Correlation between polarization curve and droplet motion inside FC flow-field channel. [GORE ${ }^{\mathrm{TM}}$ PRIMEA ${ }^{\circledR}$ SERIES $57 \mathrm{MEA}$ (Pt: 0.1/0.4 mg/ $\mathrm{cm}^{2}$ )]

Figure 6: The effect of GDL on Polarization curves for serpentine flow-field plates under a) dryer condition, b) automotive, c) stationary condition. [GORE ${ }^{\mathrm{TM}}$ PRIMEA $^{\circledR}$ SERIES 57 MEA (Pt: $\left.0.1 / 0.4 \mathrm{mg} / \mathrm{cm}^{2}\right)$ ]

Figure 7: Channel depth profiles from electro-etching process on SS430 and SS304L bipolar plates. (Average depth $=0.4 \mathrm{~mm}$ )

Figure 8: The effect of channel depth uniformity on polarization curves for serpentine flow-field plates under dryer condition. $\left(\mathrm{T}_{\text {cell }}=80^{\circ} \mathrm{C}\right.$, Anode/Cathode $\mathrm{RH}=75 / 25$, Anode/Cathode stoich $=$ 1.3/2.0, P $=101 \mathrm{kPa}$ ) [GDL: Toray TGP-H-060, GORET ${ }^{\mathrm{M}}$ PRIMEA $^{\circledR}$ SERIES 57 MEA (Pt: $\left.\left.0.1 / 0.4 \mathrm{mg} / \mathrm{cm}^{2}\right)\right]$

Figure 9: The effect of channel depth uniformity on polarization curves for serpentine flow-field plates under automotive condition. $\left(\mathrm{T}_{\text {cell }}=80^{\circ} \mathrm{C}\right.$, Anode/Cathode $\mathrm{RH}=75 / 0$, Anode/Cathode stoich $=1.3 / 2.0, \mathrm{P}=274 \mathrm{kPa}$ ) [GDL: Toray TGP-H-060, GORE ${ }^{\mathrm{TM}}$ PRIMEA $^{\circledR}$ SERIES 57 MEA (Pt: $\left.0.1 / 0.4 \mathrm{mg} / \mathrm{cm}^{2}\right)$ ]

Figure 10: The effect of channel depth uniformity on polarization curves for serpentine flowfield plates under stationary condition. $\left(\mathrm{T}_{\text {cell }}=70^{\circ} \mathrm{C}\right.$, Anode/Cathode $\mathrm{RH}=100 / 100$, Anode/Cathode stoich $=1.2 / 2.0, \quad \mathrm{P}=101 \mathrm{kPa}$ ) [GDL: Toray TGP-H-060, GORE ${ }^{\mathrm{TM}}$ PRIMEA ${ }^{\circledR}$ SERIES 57 MEA (Pt: 0.1/0.4 mg/cm²)] 
Table 1: Geometry details

\begin{tabular}{ll}
\hline Description & Value \\
\hline Active area & $25 \mathrm{~cm}^{2}$ \\
Channel width & $0.8 \mathrm{~mm}$ \\
Channel height & $0.4 \mathrm{~mm}$ in average \\
Rib-spacing width & $0.8 \mathrm{~mm}$ \\
GDL material & Toray TM TGP-H-060 \\
& Carbel CL ${ }^{\mathrm{TM}}$ \\
GDL thickness & Toray $190 \mu \mathrm{m}$ \\
& Carbel CL $400 \mu \mathrm{m}$ \\
GDL porosity & Toray $78 \%$ \\
& Carbel CL $82 \%$ \\
GDL electrical resistivity & Toray $80 \mathrm{~m} \Omega \mathrm{cm}$ \\
& Carbel CL $79 \mathrm{~m} \Omega \mathrm{cm}$ \\
MEA thickness & $35 \mu \mathrm{m}$ \\
Gasket & $178 \mu \mathrm{m}$ \\
\hline
\end{tabular}


Table 2: Experimental condition

\begin{tabular}{|c|c|c|c|c|c|c|}
\hline \multirow[t]{2}{*}{ Condition } & \multirow{2}{*}{$\begin{array}{l}\mathrm{T}_{\text {cell }} \\
\left({ }^{\circ} \mathrm{C}\right)\end{array}$} & \multirow{2}{*}{$\begin{array}{c}\text { Anode RH } \\
(\%)\end{array}$} & \multirow{2}{*}{$\begin{array}{c}\text { Cathode RH } \\
\text { (\%) }\end{array}$} & \multicolumn{2}{|c|}{ Stoichiometry } & \multirow{2}{*}{$\begin{array}{c}\text { Pressure } \\
(\mathrm{kPa})\end{array}$} \\
\hline & & & & Anode & Cathode & \\
\hline Stati & 70 & 100 & 100 & 1.2 & 2.0 & 101 \\
\hline Dryer & 80 & 75 & 25 & 1.3 & 2.0 & 101 \\
\hline Automotive & 80 & 75 & 0 & 1.3 & 2.0 & 274 \\
\hline
\end{tabular}




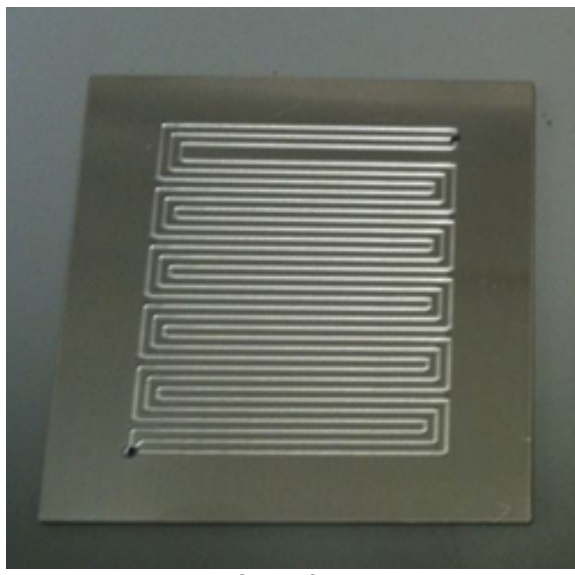

Anode

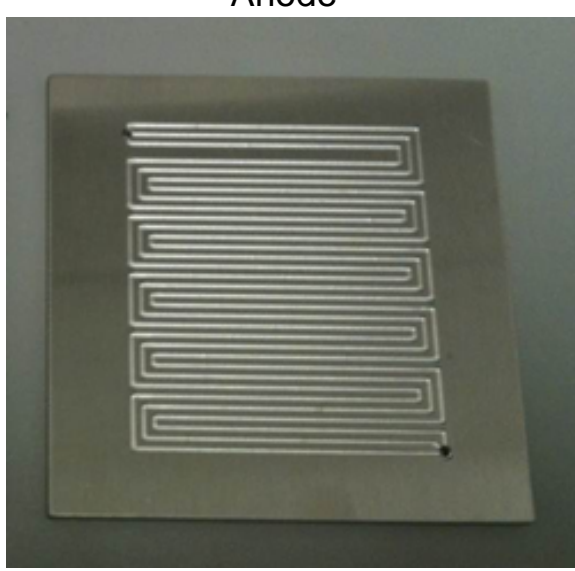

Cathode

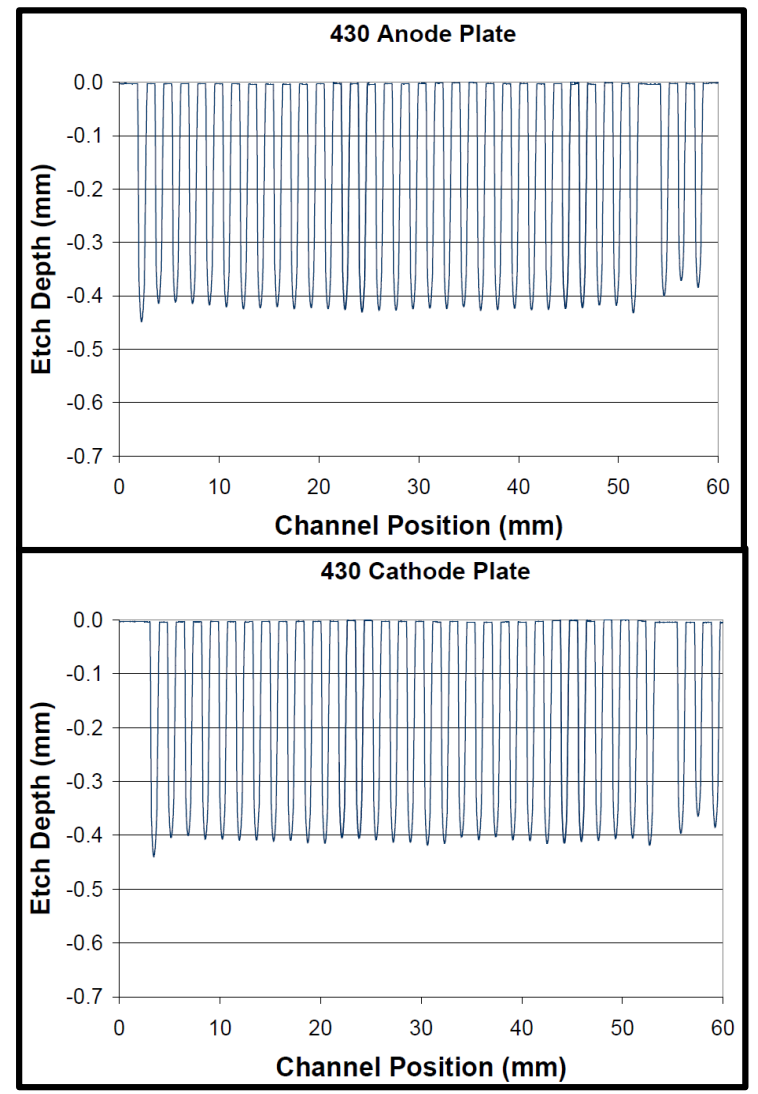

SS430

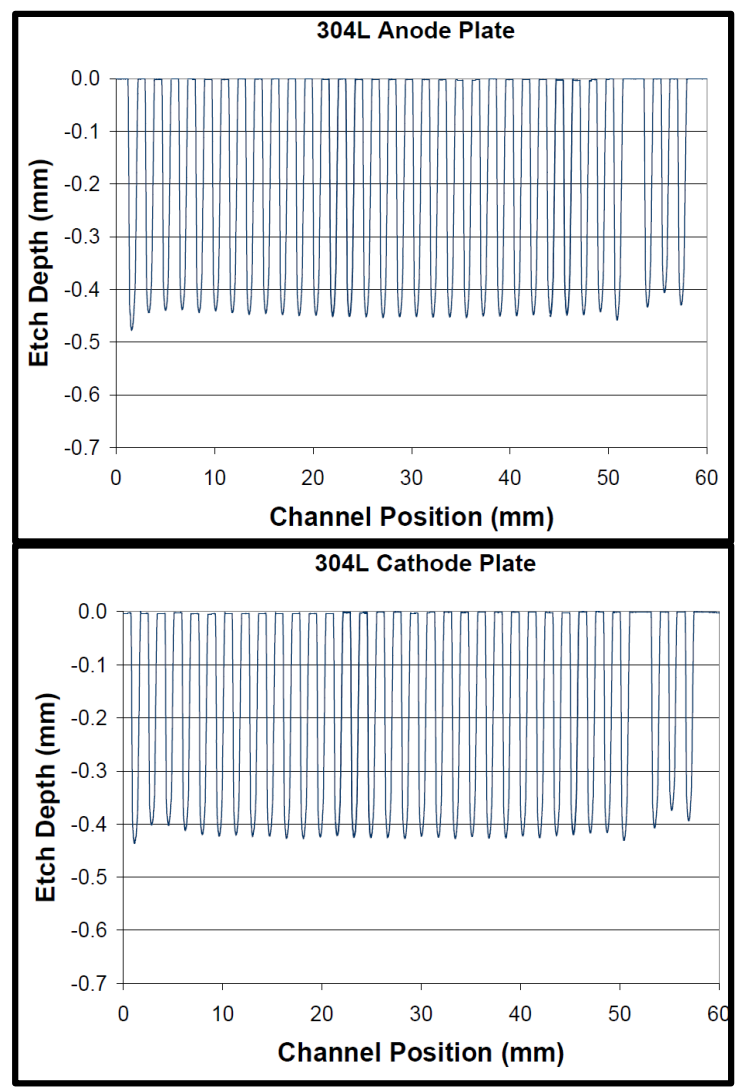

SS304L

Triple pass serpentine flow-field on $25 \mathrm{~cm}^{2}$

Figure 1: Channel depth profiles from electro-etching process on SS430 and SS304L bipolar plates (Average depth $=0.4 \mathrm{~mm}$ ). 


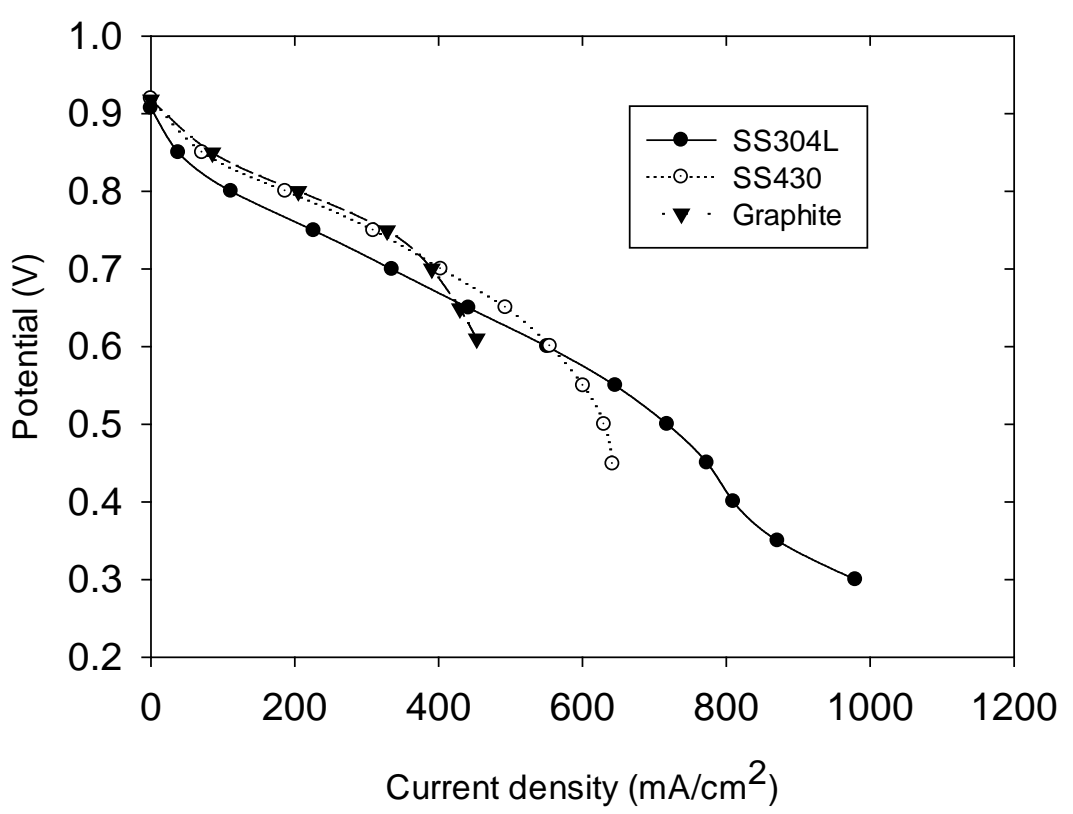

Original data

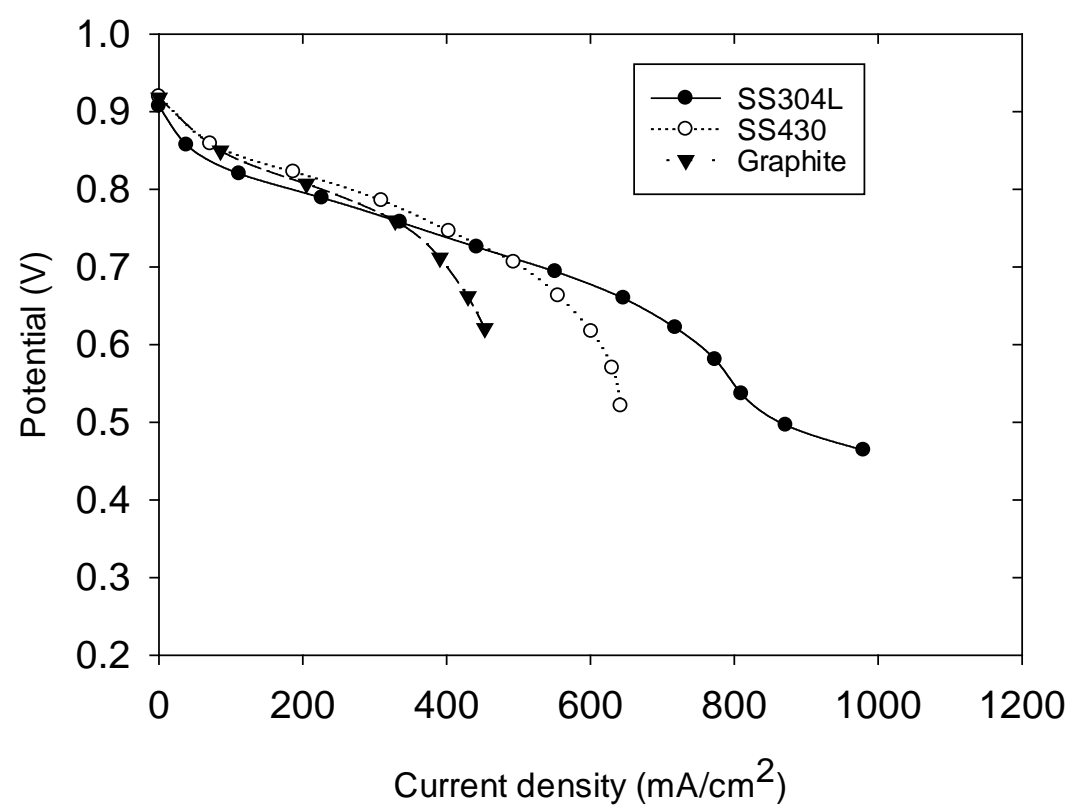

iR corrected

Figure 2: Polarization curves for serpentine flow-field plates under stationary condition. (Tcell $=70^{\circ} \mathrm{C}$, Anode/Cathode RH = 100/100, Anode/Cathode stoich = 1.2/2.0, $\mathrm{P}=101 \mathrm{kPa}$ ) [GDL: Toray TGP-H-060, GORETM PRIMEA®SERIES 57 MEA (Pt: $0.1 / 0.4 \mathrm{mg} / \mathrm{cm}^{2}$ )] 


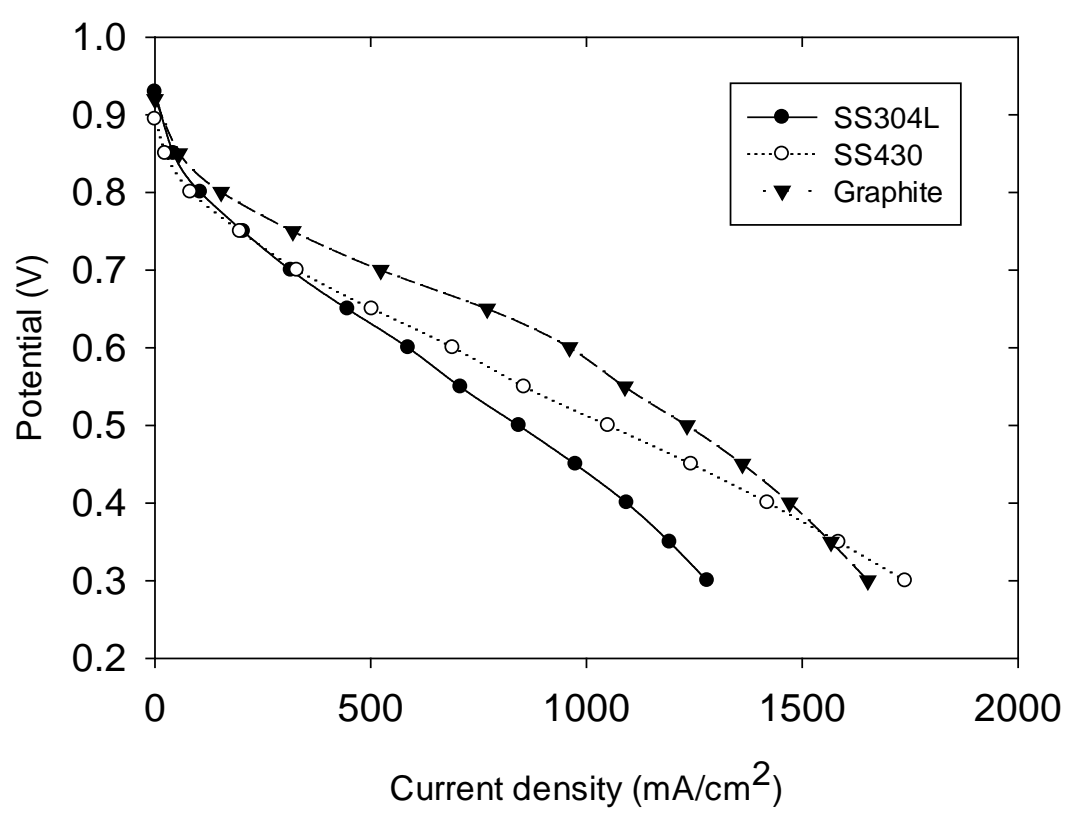

Original data

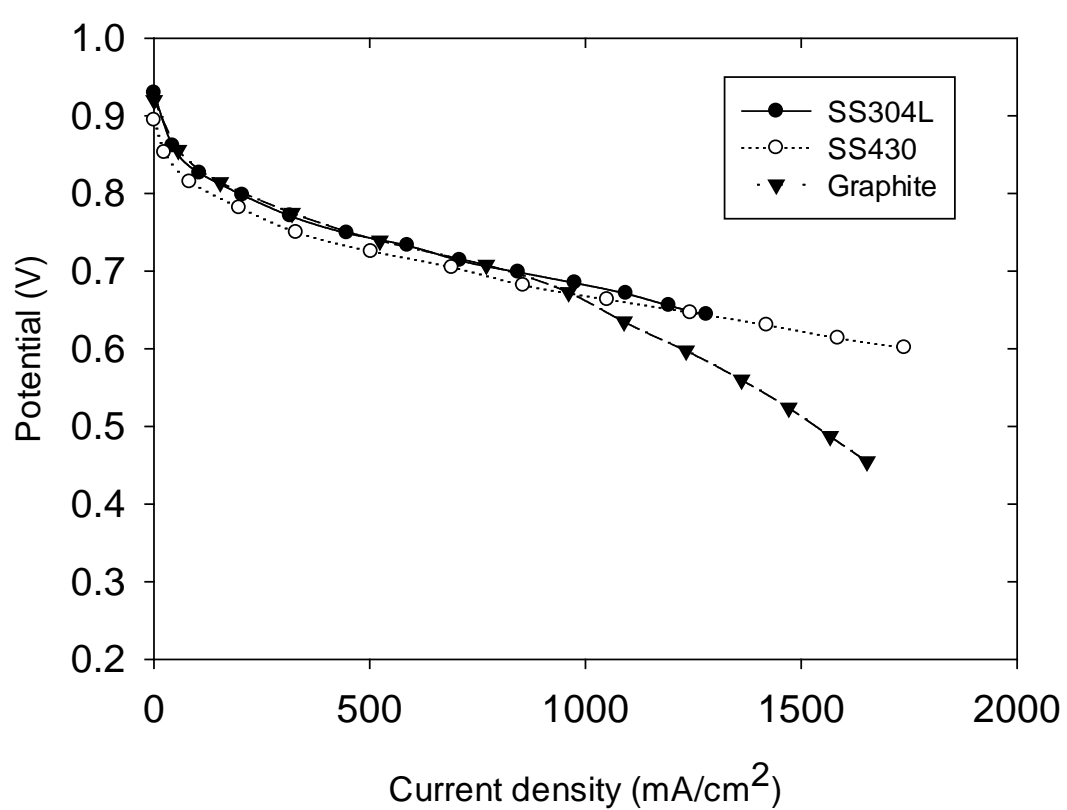

iR corrected

Figure 3: Polarization curves for serpentine flow-field plates under dryer condition. (Tcell $=80^{\circ} \mathrm{C}$, Anode/Cathode $\mathrm{RH}=75 / 25$, Anode/Cathode stoich $=1.3 / 2.0, \mathrm{P}=101 \mathrm{kPa}$ )

[GDL: Toray TGP-H-060, GORE ${ }^{\text {TM }}$ PRIMEA®SERIES 57 MEA (Pt: $0.1 / 0.4 \mathrm{mg} / \mathrm{cm}^{2}$ )] 


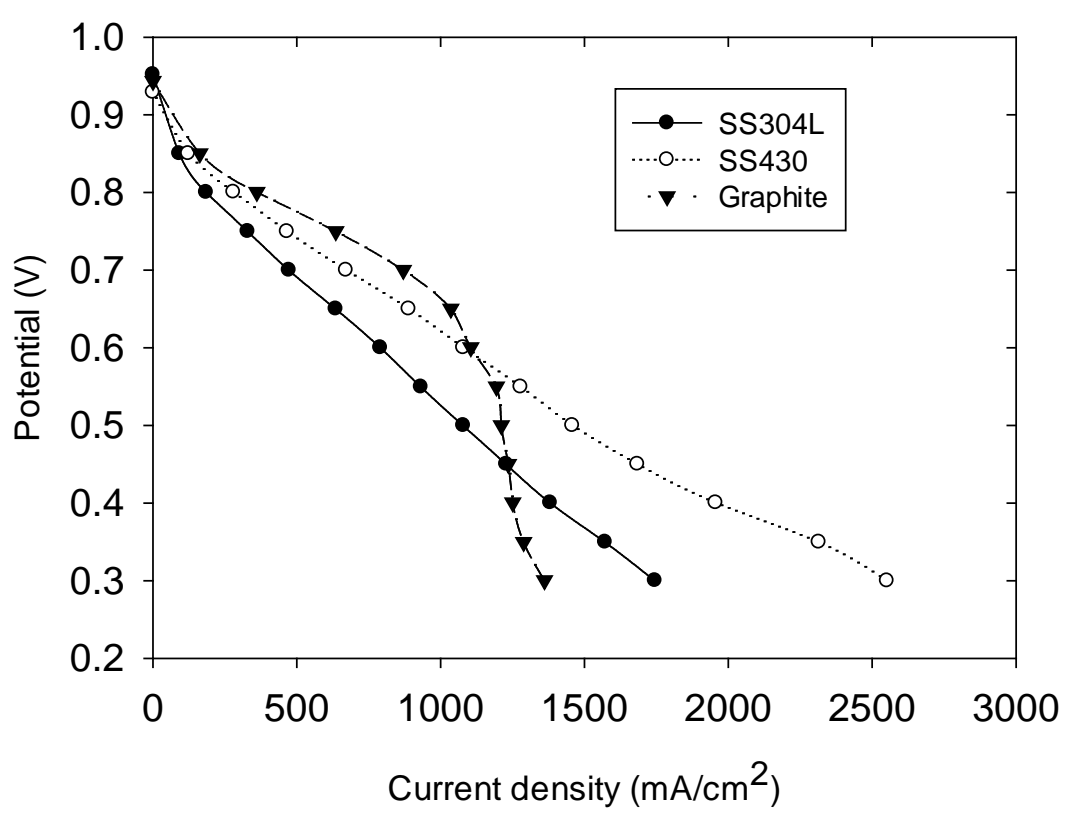

Original data

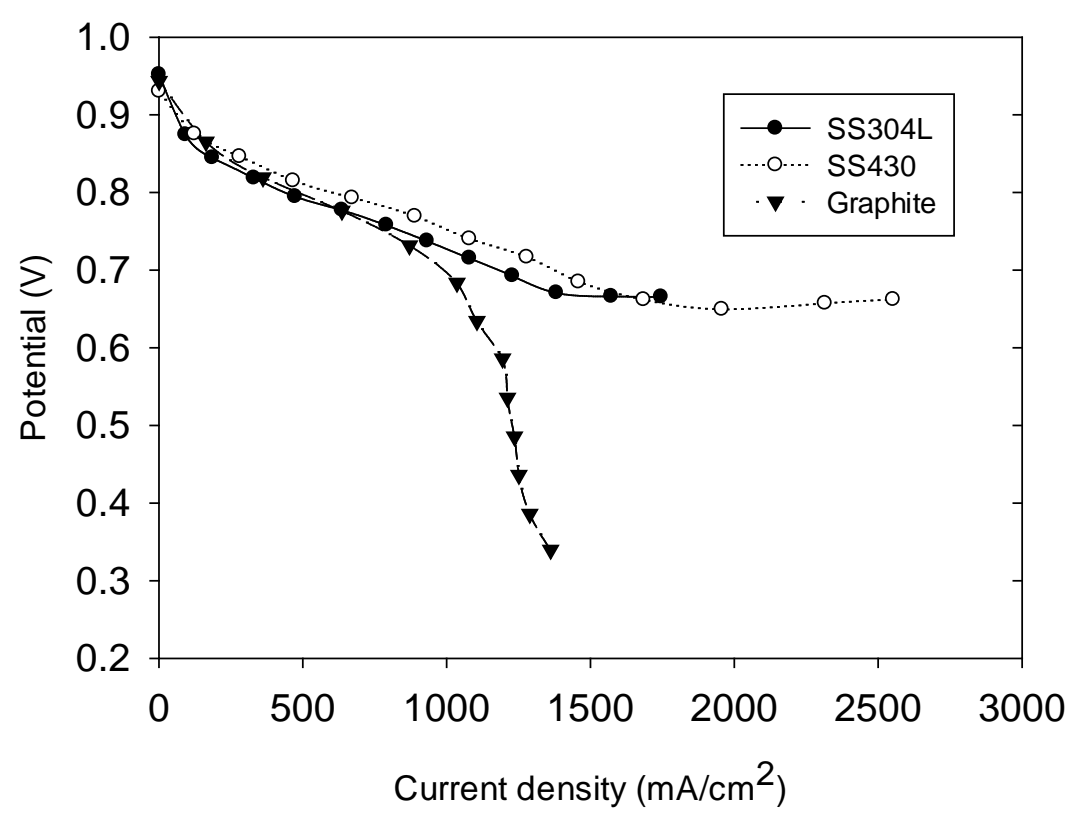

iR corrected

Figure 4: Polarization curves for serpentine flow-field plates under automotive condition. (Tcell $=80^{\circ} \mathrm{C}$, Anode $/$ Cathode $\mathrm{RH}=75 / 0$, Anode $/$ Cathode stoich $=1.3 / 2.0, \mathrm{P}=274 \mathrm{kPa}$ )

[GDL: Toray TGP-H-060, GORE ${ }^{\mathrm{TM}}$ PRIMEA ${ }^{\circledR S E R I E S ~} 57 \mathrm{MEA}\left(\mathrm{Pt}: 0.1 / 0.4 \mathrm{mg} / \mathrm{cm}^{2}\right)$ ] 


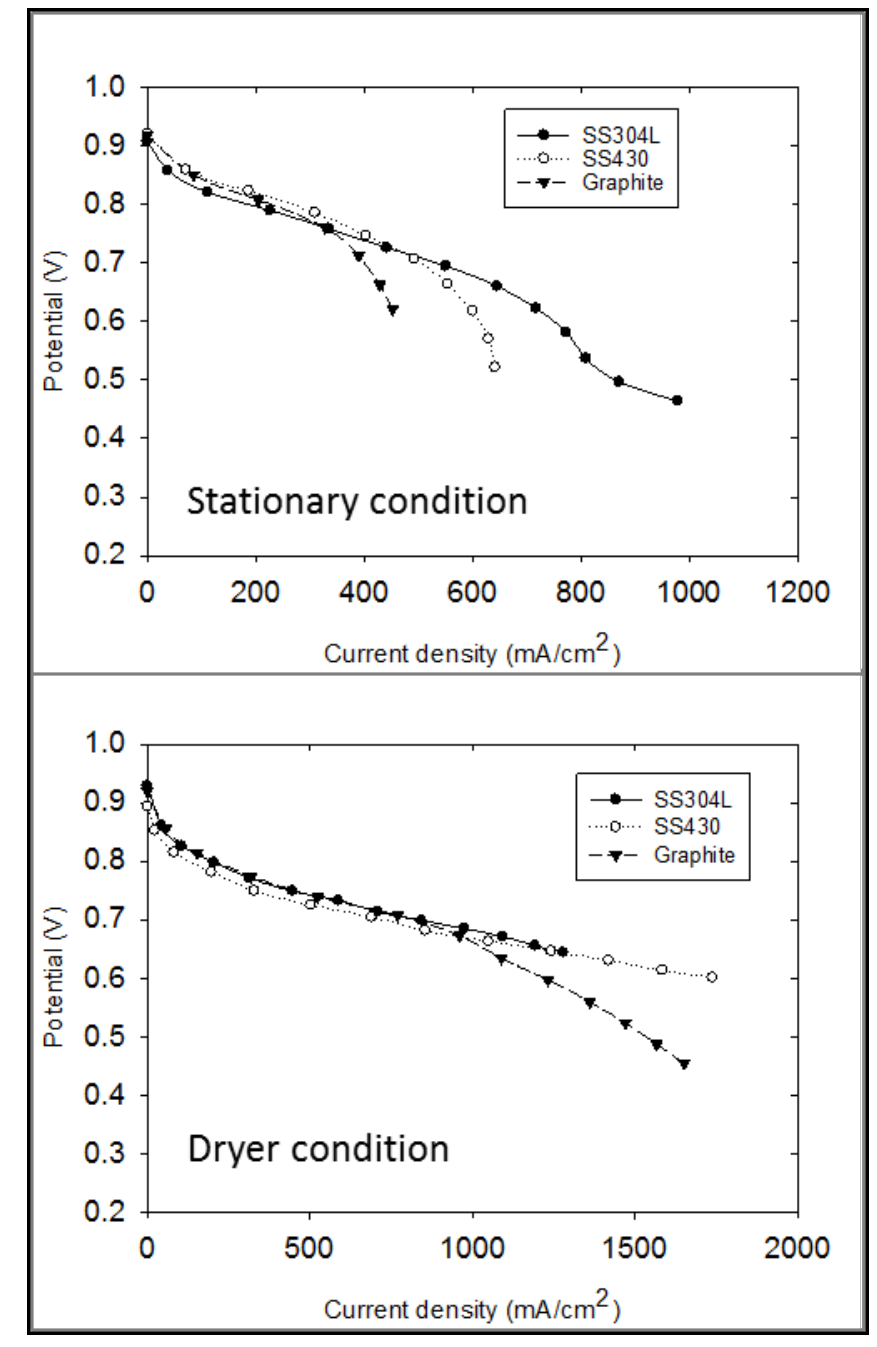

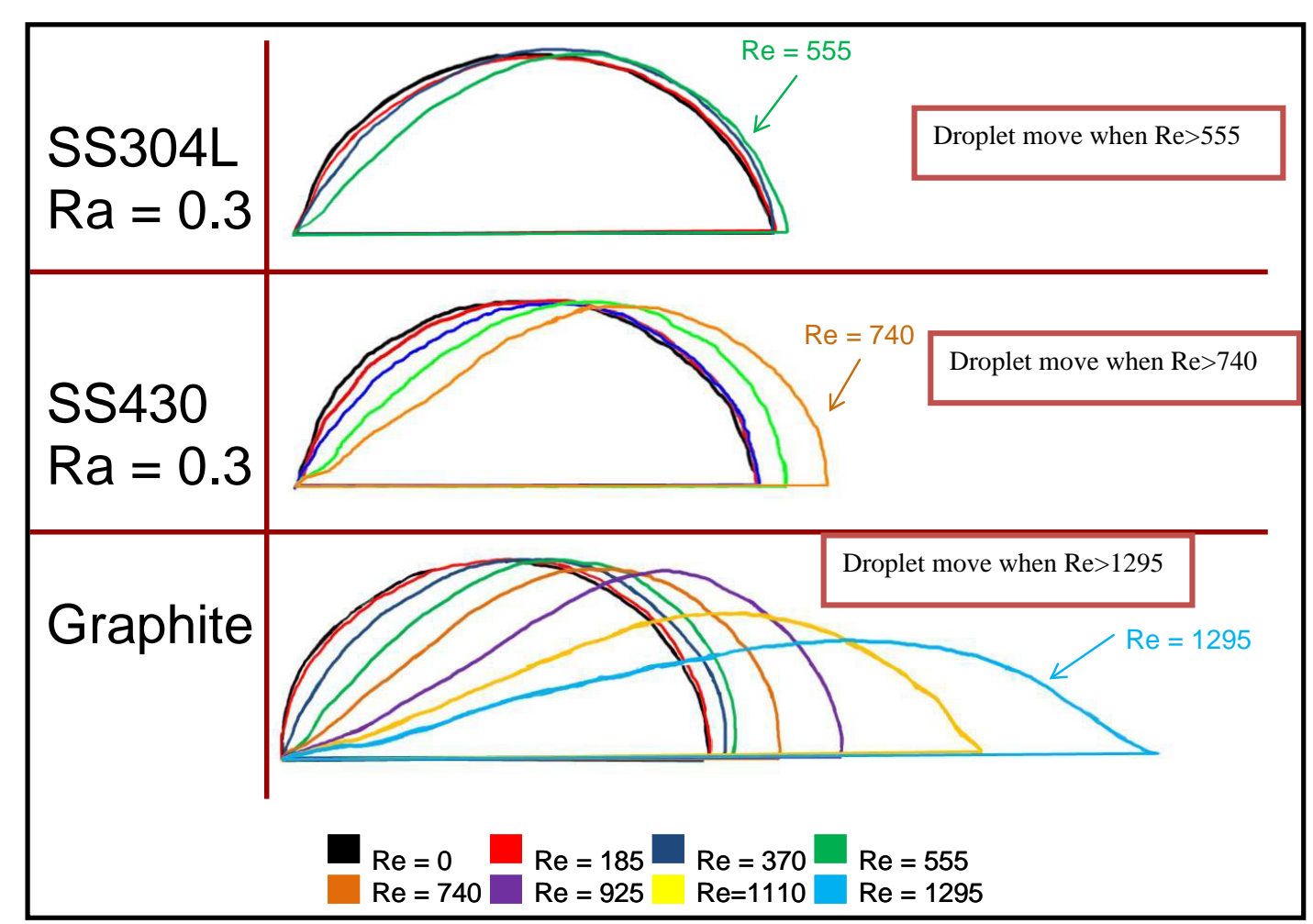

Figure 5: Comparison between polarization curve and droplet motion inside FC flow-field channel [GORE ${ }^{\mathrm{TM}}$ PRIMEA®SERIES 57 MEA (Pt: 0.1/0.4 $\left.\mathrm{mg} / \mathrm{cm}^{2}\right)$ ] 

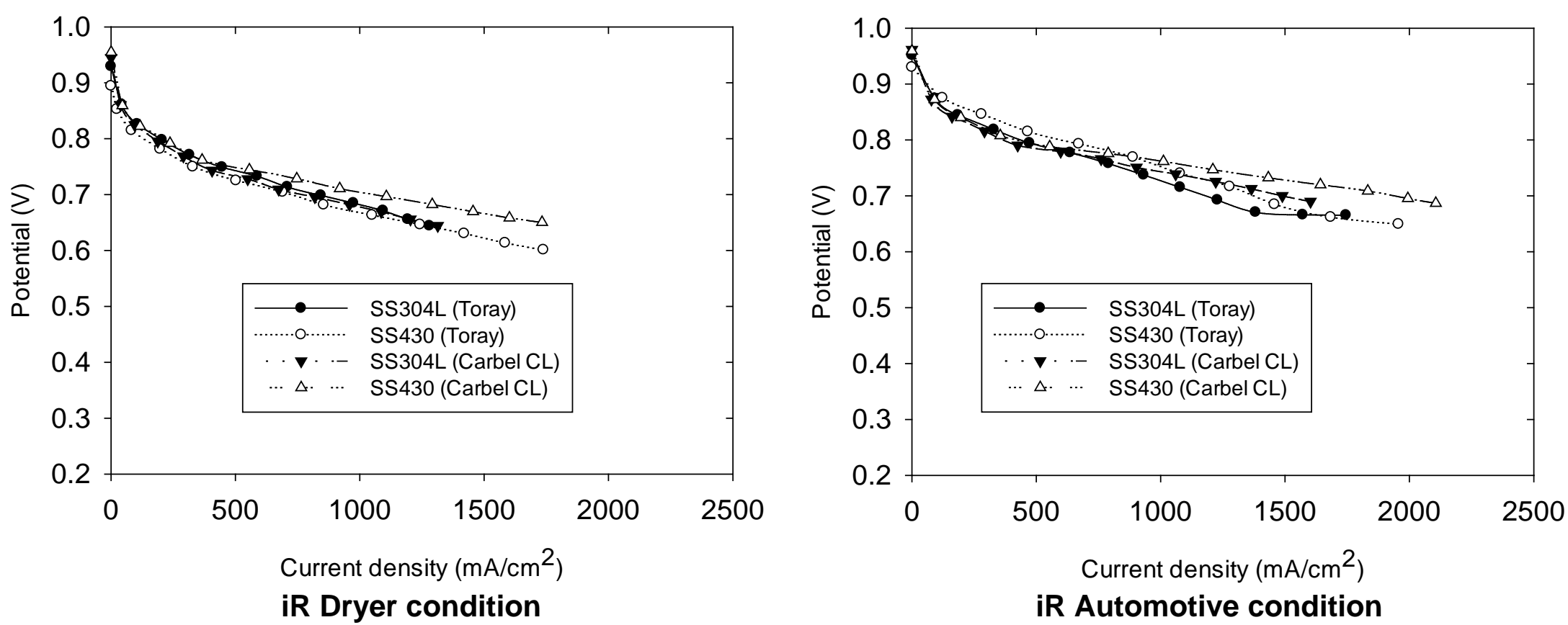

iR Automotive condition 


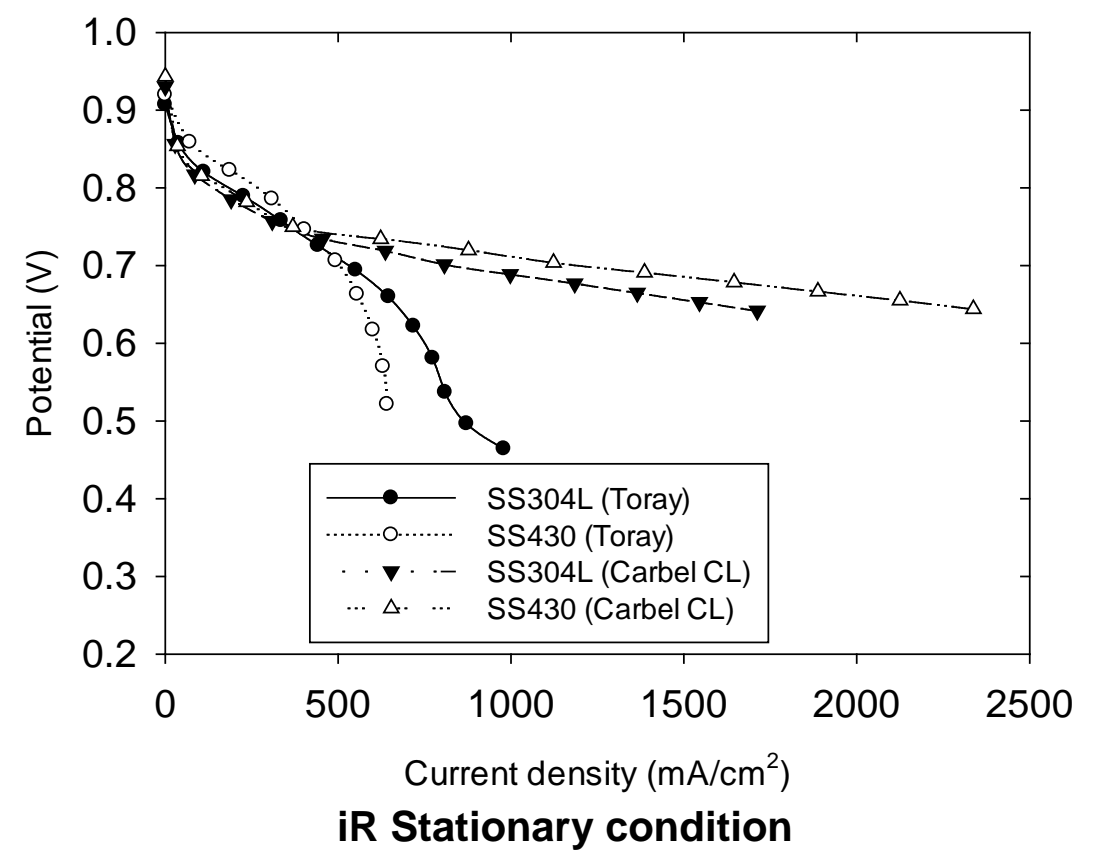

Figure 6: The effect of GDL on Polarization curves for serpentine flow-field plates under a) dryer condition, b) automotive, c) stationary condition [GORE ${ }^{\mathrm{TM}}$ PRIMEA $®$ SERIES 57 MEA (Pt: $\left.0.1 / 0.4 \mathrm{mg} / \mathrm{cm}^{2}\right)$ ] 

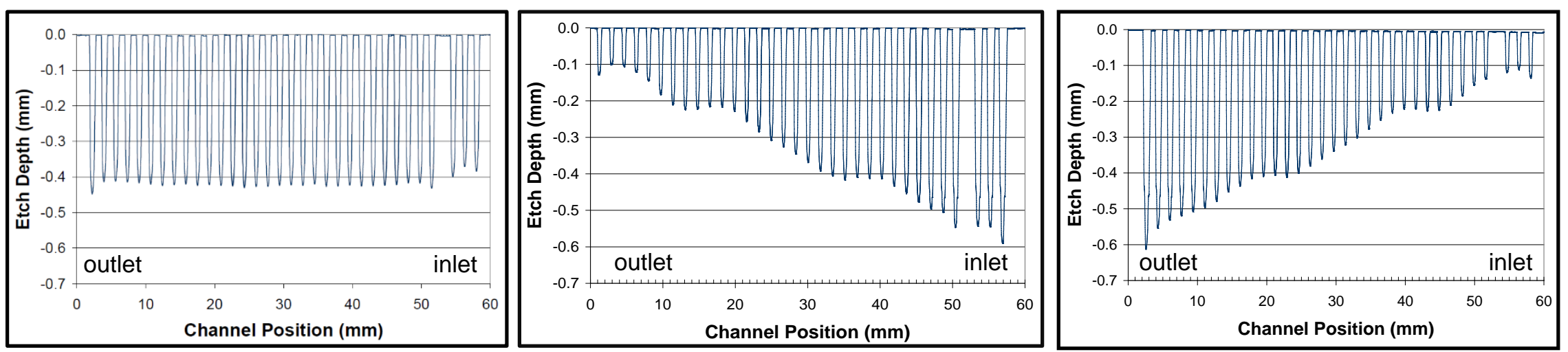

Anode

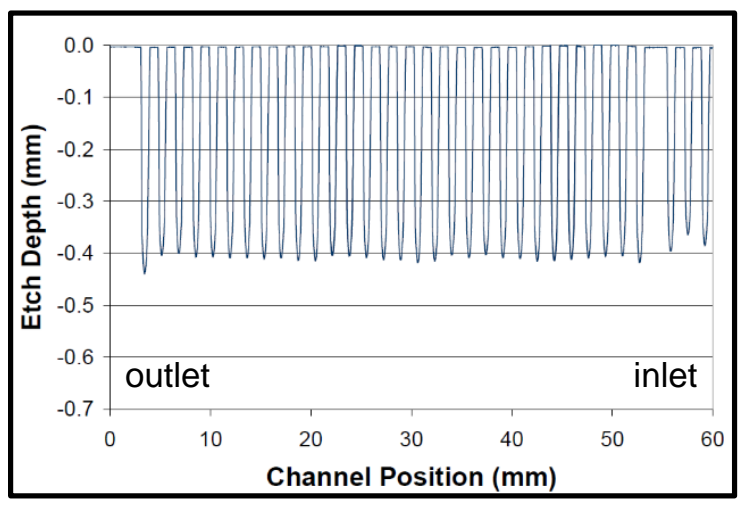

SS \# 1

Uniform

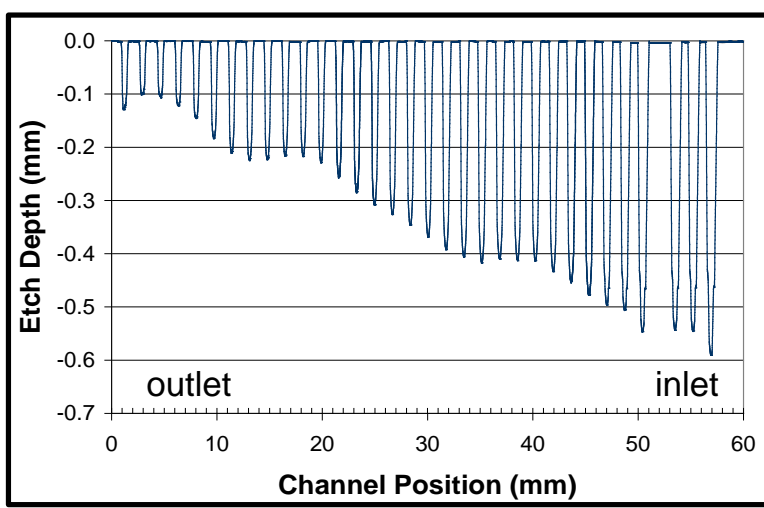

Cathode

SS \# 2

Deep inlet - Shallow outlet

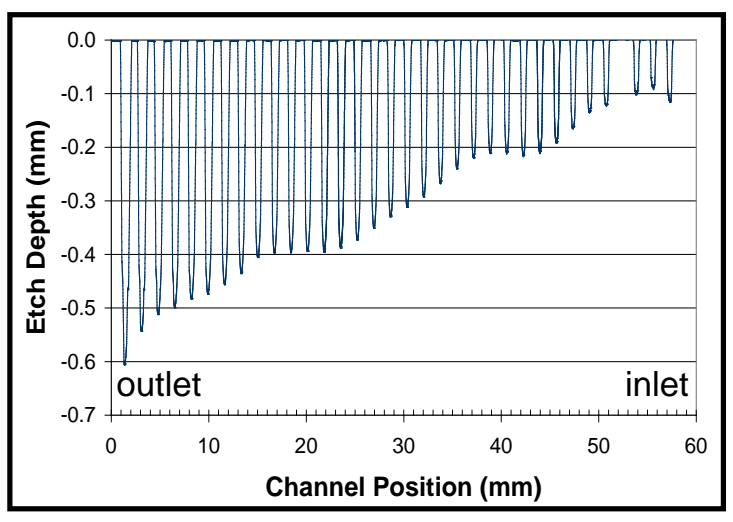

SS \# 3

Deep outlet - Shallow inlet

Figure 7: Channel depth profiles from electro-etching process on SS430 and SS304L bipolar plates (Average depth $=0.4 \mathrm{~mm}$ ) 


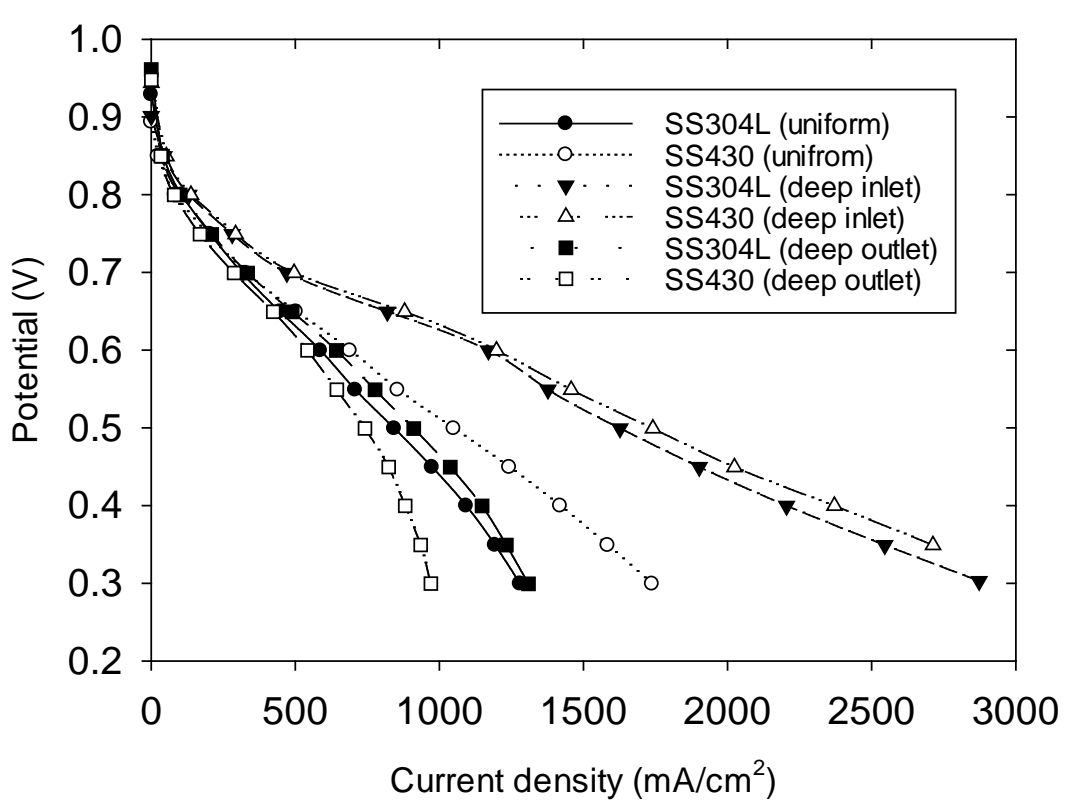

Original data

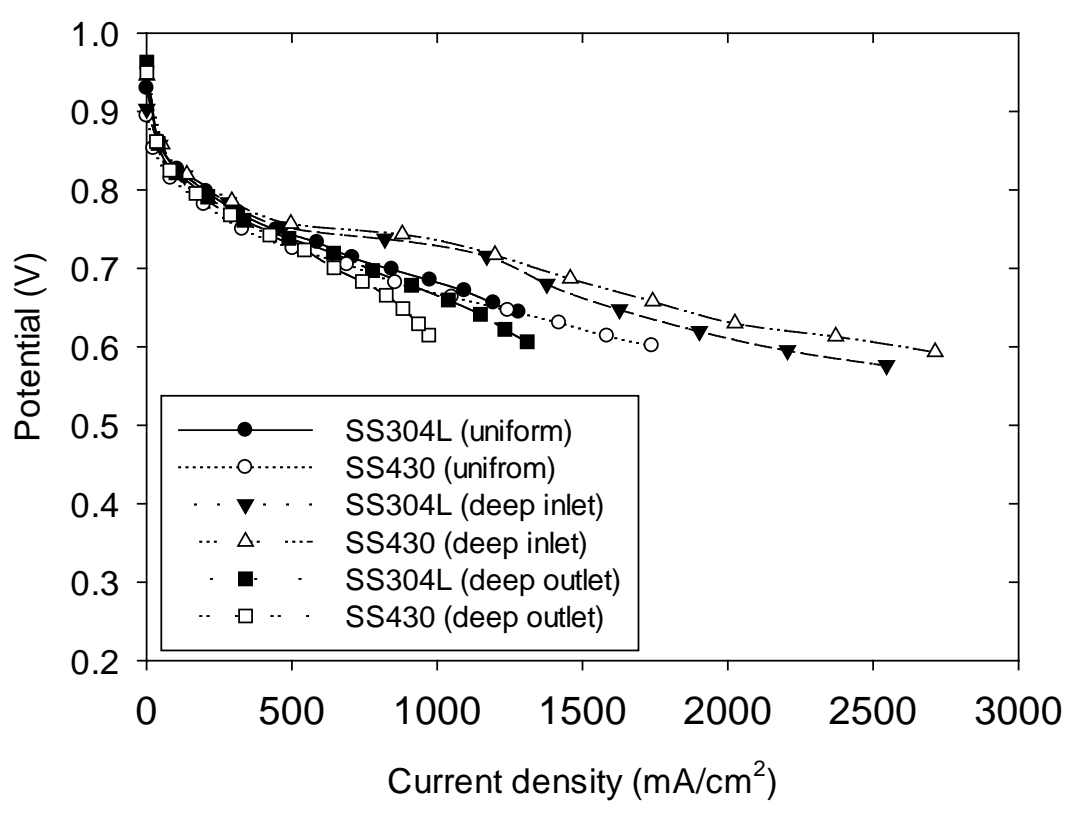

iR corrected

Figure 8: The effect of channel depth uniformity on polarization curves for serpentine flow-field plates under dryer condition.

(Tcell $=80^{\circ} \mathrm{C}$, Anode/Cathode RH $=75 / 25$, Anode $/$ Cathode stoich $=1.3 / 2.0, P=101 \mathrm{kPa}$ )

[GDL: Toray TGP-H-060, GORE ${ }^{\mathrm{TM}}$ PRIMEA®SERIES 57 MEA (Pt: $\left.0.1 / 0.4 \mathrm{mg} / \mathrm{cm}^{2}\right)$ ] 


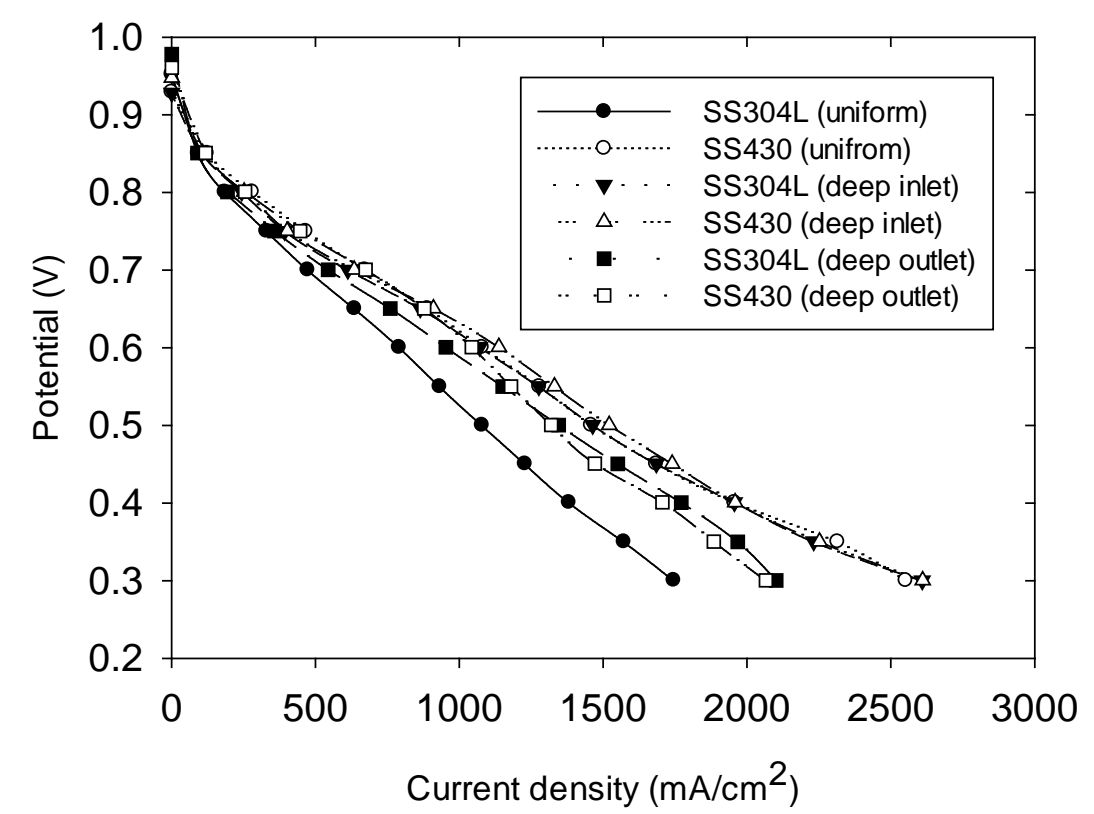

Original data

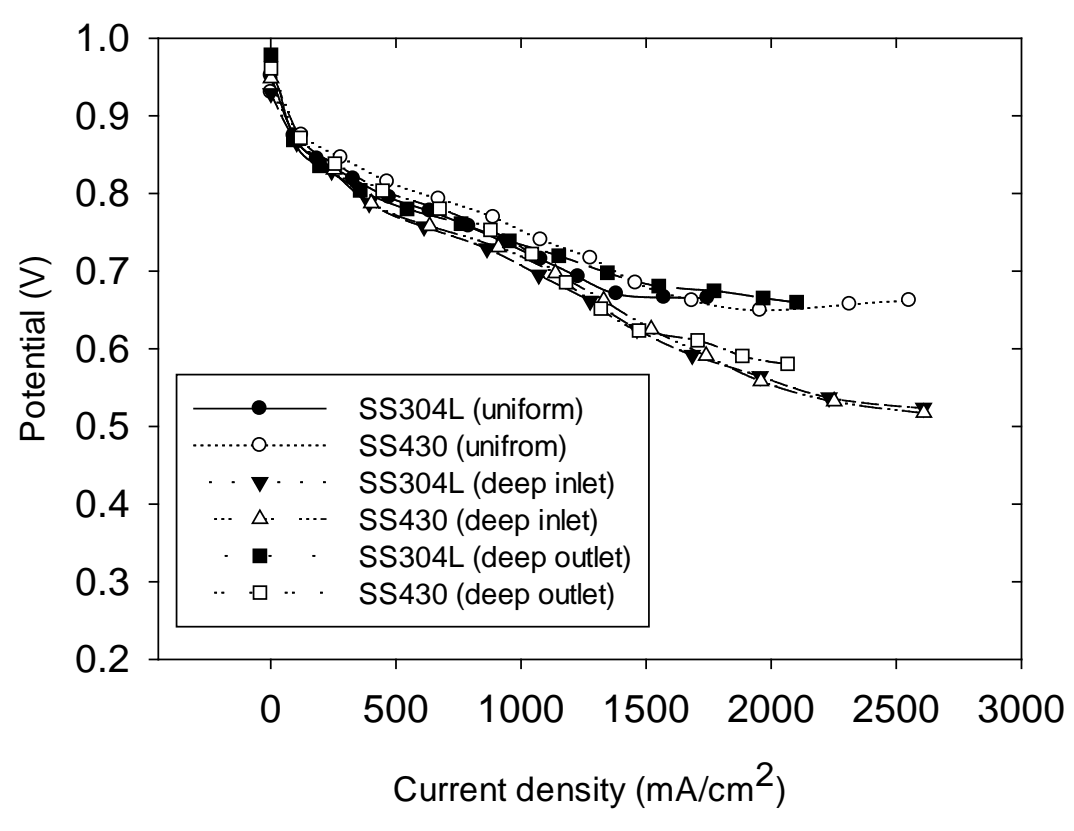

iR corrected

Figure 9: The effect of channel depth uniformity on polarization curves for serpentine flow-field plates under automotive condition.

(Tcell $=80^{\circ} \mathrm{C}$, Anode $/$ Cathode $\mathrm{RH}=75 / 0$, Anode $/$ Cathode stoich $=1.3 / 2.0, \mathrm{P}=274 \mathrm{kPa}$ )

[GDL: Toray TGP-H-060, GORE ${ }^{\mathrm{TM}}$ PRIMEA®SERIES 57 MEA (Pt: $\left.0.1 / 0.4 \mathrm{mg} / \mathrm{cm}^{2}\right)$ ] 


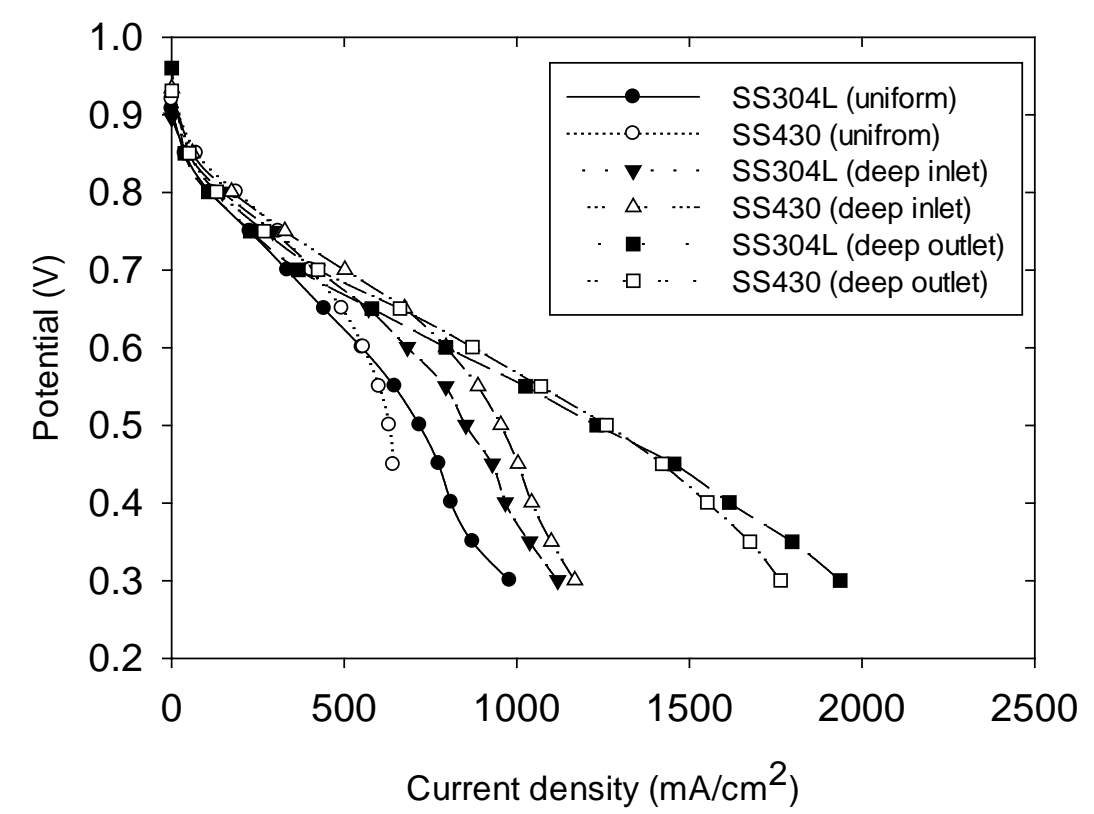

Original data

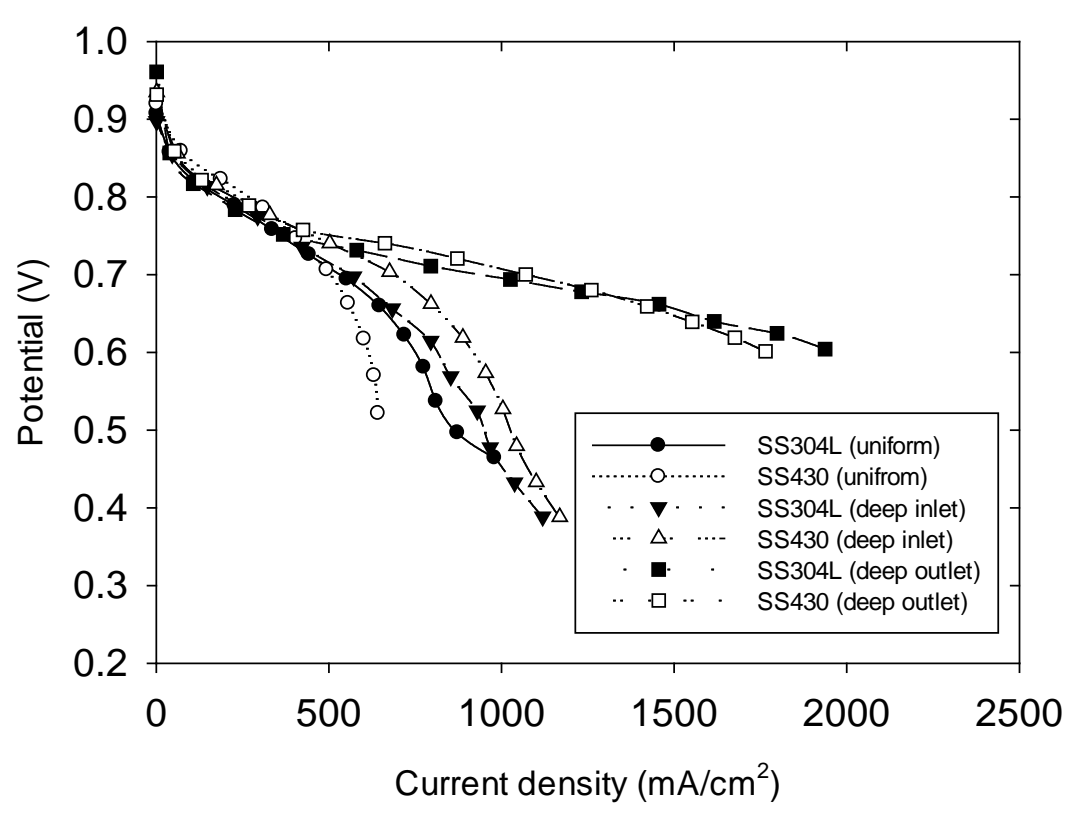

iR corrected

Figure 10: The effect of channel depth uniformity on polarization curves for serpentine flow-field plates under stationary condition.

(Tcell $=70^{\circ} \mathrm{C}$, Anode $/$ Cathode $\mathrm{RH}=100 / 100$, Anode $/$ Cathode stoich $=1.2 / 2.0, \mathrm{P}=101 \mathrm{kPa}$ )

[GDL: Toray TGP-H-060, GORE ${ }^{\text {TM }}$ PRIMEA®SERIES 57 MEA (Pt: $\left.0.1 / 0.4 \mathrm{mg} / \mathrm{cm}^{2}\right)$ ] 